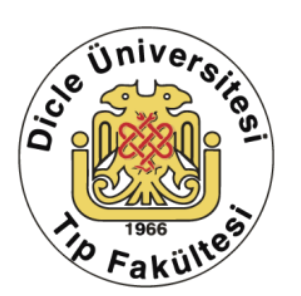

\title{
Are soil and waterborne parasitic infections health risk for worker populations in southeast Turkey?
}

\author{
Sibel Ak ${ }^{1}$ Fadime Eroğlu², Ali İhsan Nergiz ${ }^{3}$, Furkan Hıyamlı ${ }^{4}$ \\ 1 Department of Imminology, School of Medicine, University of Firat, Elazığ, Turkey \\ 2 Department of Biotechnology, Institute of Science, University of Cukurova, Adana, Turkey \\ 3 School of Medicine, University of Cerrahpasa, Istanbul, Turkey \\ 4 Seckin High School, Gaziantep, Turkey
}

Received: 07.02.2017 Revised: 12.04.2017 Accepted: 04.05.2017

\begin{abstract}
Objective: The soil and waterborne parasitic infections rate is high degree in developed and developing countries. Migratory workers have greater exposure to these parasitic infections and a lot of morbidity due to these infections in workers.

For this reason, we aimed to investigate the presence of soil and waterborne parasites in the Gaziantep Organized Industrial Zone of southeast Turkey.

Methods: A total of 25 environmental samples (18 soil samples and 7 water samples) were taken from The Gaziantep Organized Industrial Zone, in two different seasons (summer and winter). All of the samples were screened for parasites using microscopic examination and culture methods. The parasites were genotyped with polymerase chain reaction and DNA sequencing analysis.

Results: The prevalence of soil and water transmitted parasites was found to be positive $52 \%(13 / 25)$ in summer while there is no any parasites in winter. It was found 22.3\% (4/18) Acanthamoeba (genotype4), 16.6\% (3/18) Ascaris lumbricoides, 11.1\% (2/18) Strongoides stercoralis in soil samples and 14.3\% (1/7) Acanthamoeba (genotype 4), 42.9\% (3/7) Blastocystis (subtype3) in all of water samples.

Conclusion: The migratory worker waves have always shaped the ethnic composition and public health problem of the province of Gaziantep. Climate change has the potential to influence prevalence of parasite and our study has shown that increased prevalence of parasite in summer. The global target for the coming years should be to remove the deaths from earth and waterborne parasitic infections in the worker populations. Thus, we prevent the distribution of parasitic infections in our country.
\end{abstract}

Keywords: Soil, water, parasite, migratory

DOI: $10.5798 /$ dicletip.319779

Yazışma Adresi / Correspondence: Fadime Eroğlu, Department of Biotechnology, Institute of Science, University of Cukurova, Adana, Turkey e-mail: eroglufadime@hotmail.com 


\section{Güneydoğu Anadolu'daki işçi popülasyonları için toprak ve su kaynaklı paraziter enfeksiyonlar sağlık riski oluşturur mu?}

\section{Özet}

Amaç: Gelişmiş ve gelişmekte olan ülkelerde toprak ve su kaynaklı paraziter enfeksiyon oranı yüksektir. Göçmen işçiler, bu paraziter enfeksiyonlara daha fazla maruz kalmaktadırlar ve işçilerdeki bu enfeksiyonlardan dolayı ölümler görülmektedir. Bu nedenle, bu çalışmada Türkiye'nin güneydoğusundaki Gaziantep Organize Sanayi Bölgesindeki toprak ve su ile bulaşan parazit varlığını araştırmayı amaçladık.

Yöntemler: Gaziantep Organize Sanayi Bölgesi'nden (kış ve yaz) iki farklı mevsimde toplam 25 çevre örneği (7 su örneği ve 18 toprak örneği) alınmıştır. Örneklerin hepsi mikroskobik inceleme, kültür yöntemleri ile parazit varlığı açısından incelendi. Parazitler polimeraz zincir reaksiyonu ve DNA dizi analizi ile genotiplendirildi.

Bulgular: Yaz mevsiminde alınan toprak ve su örneklerinde \%52 (13/25) oranında parazit tespit edilirken, kıș mevsiminde alınan örneklerde parazit bulunmadı. Toprak örneklerinde \%22,3 (4/18) Acanthamoeba (genotype 4); $\% 16,6$ (3/18) Ascaris lumbricoides, \%11,1 (2/18) Strongoides stercoralis ve su örneklerinde \%14,3 (1/7) Acanthamoeba (T4), \%42,9 (3/7) Blastocystis (subtip3) bulundu.

Sonuç: Göç eden iş̧̧i dalgaları, Gaziantep şehrinin etnik bileşimini ve halk sağlı̆̆ sorununu her zaman şekillendirmiştir. İklim değişikliği, parazit dağılımını etkileme potansiyeline sahiptir ve bizim çalışmamız yaz aylarında parazit prevalansının arttığını göstermektedir. Önümüzdeki yıllardaki global hedefimiz işçi popülasyonlarındaki toprak ve su kaynaklı paraziter enfeksiyonlara bağlı ölümleri ortadan kaldırmak olmalıdır. Böylece ülkemizdeki parazit enfeksiyonlarının hastalıklarının dağılımını önlemiş oluruz.

Anahtar kelimeler: Toprak, su, parazit, göçmen

\section{INTRODUCTION}

Soil and water transmitted parasites are among the most common infectious agents worldwide and affect the poorest and most deprived communities. More than 1.5 billion people, or $24 \%$ of the world's population, are infected with soil and water transmitted parasitic infections worldwide ${ }^{1}$. Parasitic infections with a soil and water transmission that cause human infections are Acanthamoeba, Ascaris lumbricoides, Blastocystis and Strongoides stercoralis parasites ${ }^{2-4}$. These parasites are considered to have a cosmopolitan distribution 5,6 .

Acanthamoeba species have gained importance in public health as the causative agents of granulomatous encephalitis, disseminated cutaneous diseases and keratitis ${ }^{2}$. Ascaris lumbricoides cause ascariasis infestation and there is every possibility that humans may suffer from deleterious morbidity conditions due to Ascaris lumbricoides such as appendicitis, haemorrhagic infarctions, and perforation of intestine and intestinal obstructive bolus ${ }^{7}$. Blastocystis have considered responsible for the gastrointestinal symptoms ${ }^{8}$. The conflicting reports about the pathogenicity of Blastocystis may be due to the existence of different subspecies ${ }^{9}$. Strongyloides stercoralis causes a gastrointestinal infection that has several distinctive features ${ }^{10}$.

Soil and water transmitted parasitic infectious outbreaks have economic consequences beyond the cost of health care for affected patients, their families and contacts. In addition, parasitic infections create a loss of labor in the national economy. The province of Gaziantep is located in southeast of Turkey and this province plays an important role in the Turkish economy with its industrial and commercial infrastructure; the province acts as a bridge between important regions due to its geographical location as a commercial center ${ }^{11}$. There are eight different industry zones in the Gaziantep Organized Industrial Zone and the branches of the manufacturing industry make 
up $28.72 \%$ of the economically active population ${ }^{11}$. The total population of migrant and seasonal workers in the Gaziantep located in southeast Turkey is estimated to be as large as 5 million. The all-cause work-related death rate for migrant and seasonal workers was the highest for all occupations. Therefore, the aim of this study was to determine the presence of soil and water transmitted parasites in Gaziantep using microscopic examination, culture and genotype with PCR methods. In addition the correlation of temperature conditions on the distribution of these parasites was investigated.

\section{METHODS}

\section{Study Area}

The manufacturing industry in Gaziantep is comprised of eight groups, namely food, textile, chemicals-plastics,

automotive subcontractors, building subcontractors, leather and processed leather products and forest-wood-paper products industries in the Gaziantep Organized Industrial Zone (Figure 1). There are approximately 20.000 employees in each industrial zone.

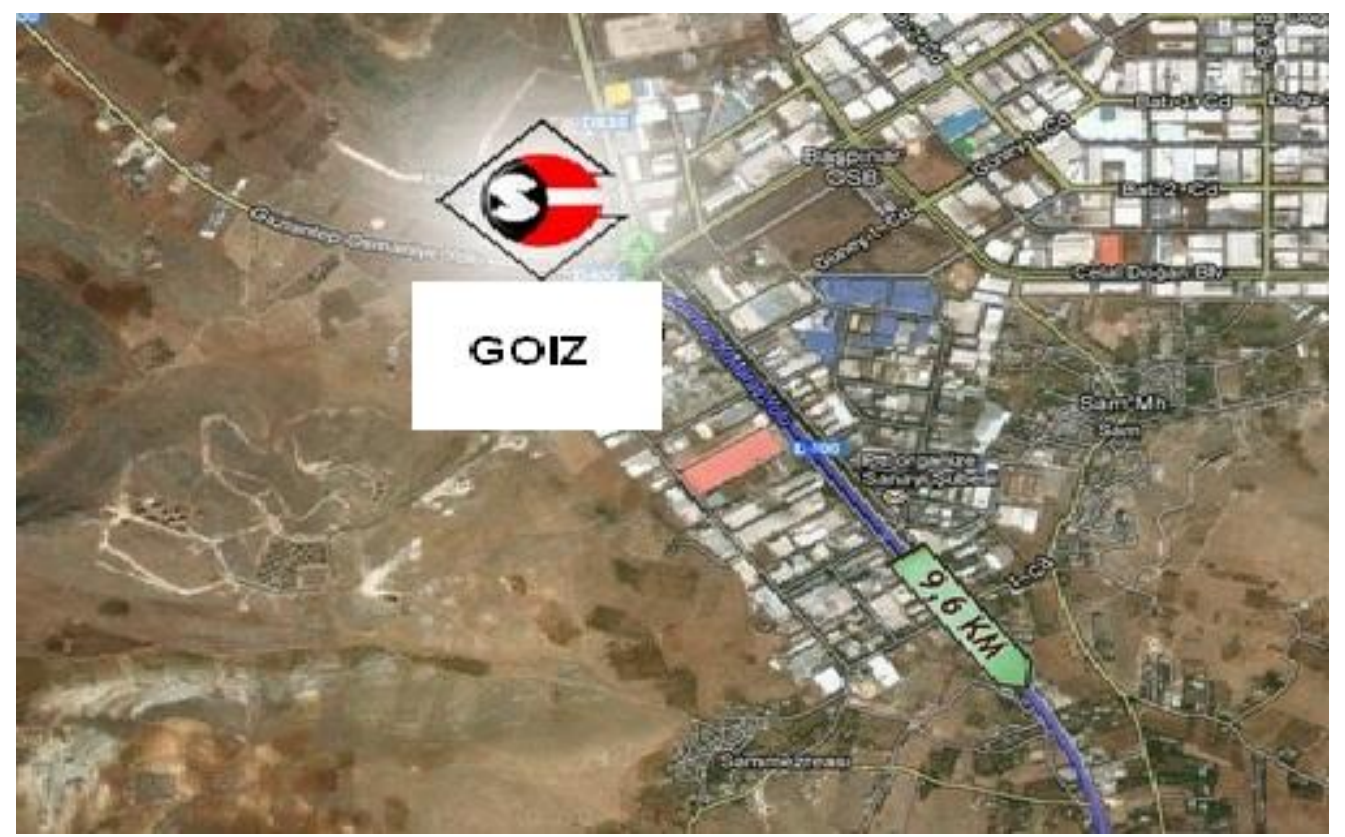

Figure 1: The Gaziantep Organized Industrial Zone (GOIZ) is located in center of Gaziantep province and there are approximately 20000 employees in each industrial zone.

\section{Collection of Samples and Time}

A total of 7 water and 18 soil samples were taken from Gaziantep Organized Industrial Zone, in two different seasons (winter and summer). All of the water samples were collected from the center of the industrial zone using one liter sterile polyethylene bottles. Approximately a pint (two cups) of the soil samples mixture (called the composite sample) is then placed in a soil sample bag which is often lined with plastic in different areas of the industrial zone (Figure 2). All of the samples were collected from this area in two different seasons' terms. The first season was winter and the average temperature was in between $4^{\circ} \mathrm{C}$ and $7^{\circ} \mathrm{C}$, the second season was summer and the average temperature was in between $24^{\circ} \mathrm{C}$ and $28^{\circ} \mathrm{C}$. 


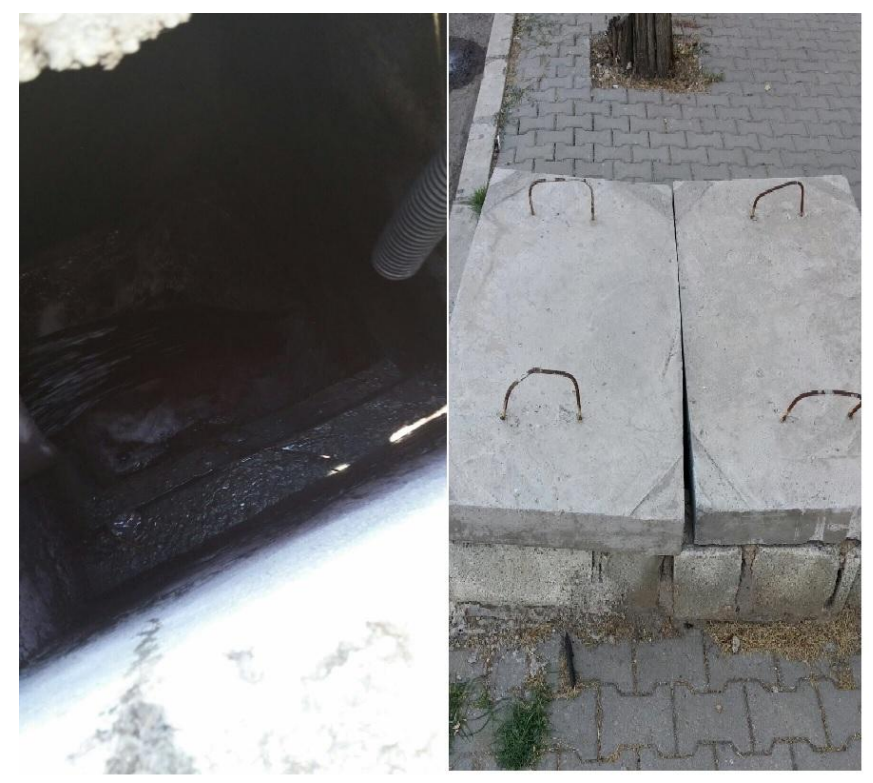

Figure 2: There are a lots of waste water system in center of Gaziantep Organized Industrial Zone (GOIZ).

\section{Microscopic Examination}

The soil samples were placed in a small crucible with $5 \mathrm{ml}$ of sterile distilled water and thoroughly ground up with a glass rod. The resultant suspension was then poured off into a $5 \mathrm{ml}$ sterile flask. The sediment was washed in $5 \mathrm{ml}$ sterile distilled water and the suspended matter poured off into the same flask. A sample is pipetted from immediately under the surface of the suspension on to the platform of a microscope slide, immediately covered by a cover-slip and allowed to solidify, then they were examined under a light microscope with magnification 40X (Olympus CX41, Australia).

Approximately $500 \mathrm{ml}$ water samples were filtered using nitrocellulose membrane $[0.45$ $\mu \mathrm{m}$ diameter, $1.3 \mu \mathrm{m}$ pore size, Millipore Corporation, Bedford, Madison) at a flow of 250 $\mathrm{mL} / \mathrm{min}$ through a flat bed membrane filtration system. Sediment trapped on the membrane filter was scraped by using an adequate amount of $0.1 \%$ Tween-80 and was aspirated to $10 \mathrm{~mL}$ upon centrifugation at $3000 \mathrm{x}$ g for 15 minutes (Thermo Scientific, United States). A sample was pipetted from immediately under the surface of the suspension on to the platform of a microscope slide and the preparation was examined under a light microscope with magnification 40X (Olympus CX41, Australia).

\section{Culture}

Soil samples (2 g) were dissolved in $5 \mathrm{ml}$ of distilled sterile water and $150 \mu$ l of each samples was inoculated onto $2 \%$ non-nutrient agar plates seeded with heat killed E. coli. After the inoculation of the samples, all plates were incubated at $27 \mathrm{oC}$ and examined daily for presence of Acanthamoeba for up 2 weeks using inverted microscope (Olympus ckx41, Australia). Acanthamoeba isolates were harvested at density of $2 \times 105$ parasite $/ \mathrm{ml}$. The cells were pelleted $(1000 \mathrm{~g}$ ) for $10 \mathrm{~min}$ at room temperature and washed 3 times with phosphate buffered saline (PBS) (pH 7.2). Cell pellets were used for DNA extraction.

Separately, $500 \mathrm{ml}$ of water samples were filtered through a cellulose nitrate filter, 0.45 $\mu \mathrm{m}$ diameter (Millipore Corporation, Bedford Madison) with a weak vacuum (flow rate, 1.3 $\mathrm{ml} / \mathrm{min}$ ) and scraped using sufficient amount of normal saline solution and was aspirated to 5 $\mathrm{ml}$ by centrifugation for 15 minutes at $1800 \mathrm{x}$. The waters were inverted on $2 \%$ non-nutrient agar plates onto which heat killed E. coli were poured and incubated at $27^{\circ} \mathrm{C}$.

\section{Polymerase Chain Reaction (PCR) Assay}

The DNA extraction was performed using the DNA isolation kit (Qiagen, Hilden, Germany). The DNA amplification reaction was performed, using the JDP1 and JDP2 primers, to amplify a 423-551 bp fragment of 18S rRNA gene in Acanthamoeba and Acanthamoeba PCR methods employed have been described previously by Schroeder et al ${ }^{12}$.

The DNA samples were subjected to PCR amplification using Sequence Tagged Sites (STS) primer with seven sets of specific primers (SB83, SB155, SB227, SB332, SB340, SB336 and SB337) for genotyping of Blastocystis species from subtype 1 to subtype 713. Blastocystis PCR methods have been 
analyzed according to Yoshikawa et al.'s study protocol.

\section{DNA sequencing}

All of Acanthamoeba PCR products were purified using a SentroPure DNA purification kit (Sentromer DNA, Istanbul, Turkey) and they were sequenced with DNA sequencing kit Big Dye TerminatorTM (Applied Biosystems, California, USA) according to the manufacturer's instructions. DNA sequencing was performed by ABI Prism 310TM Genetic Analyzer (Applied Biosystems, California, USA). The DNA sequences obtained were processed using GenBank and checked with basic local alignment search tool (BLAST) analysis software (www.ncbi.nlm.nih.gov/BLAST).

\section{RESULTS}

Overall, 25 environmental sources were screened for soil and water transmitted parasites in the Gaziantep Organized Industrial Zone. According to the results of microscopic examination, 52\% (13/25) parasites were found to be positive in environmental sources in summer season while we did not find any parasites in winter season. It was found $22.3 \%$ (4/18) Acanthamoeba, 16.6\% (3/18) Ascaris lumbricoides, $\quad 11.1 \% \quad(2 / 18) \quad$ Strongoides stercoralis in soil samples and $14.3 \%(1 / 7)$ Acanthamoeba, 42.9\% (3/7) Blastocystis, in water samples (Table 1). All of Acanthamoeba isolates were identified genotype 4 with PCR and DNA sequencing analysis. In addition we found only subtype 3 among Blastocystis isolates the results of according to PRC methods in this study (Figure 3).

Table 1: The prevalence of soil and water transmitted parasites in Gaziantep Organized Industrial Zone in two different season (winter and summer).

\begin{tabular}{l}
\hline ParasitesSoil (\%) Water (\%) \\
\hline Winter Summer Winter Summer \\
Acanthamoeba $022.3(4 / 18) 014.3(1 / 7)$ \\
Ascaris lumbricoides $016.6(3 / 18) 00$ \\
Blastocystis $00042.9(3 / 7)$ \\
Strongoides stercoralis $011.1(2 / 18) 00$ \\
\hline
\end{tabular}

\section{DISCUSSION}

Seasonal workers perform strenuous tasks and are exposed to a wide variety of occupational risks and hazards. Low socioeconomic status and poor access to health care also contribute to existing health problems in this population ${ }^{14}$. Potential seasonal work-related health problems include accidents, parasite infectious, pesticide-related illnesses, dermatitis, reproductive health problems, health problems of children of farm workers and climate-caused illnesses ${ }^{15}$. Soil and water transmitted parasite infections have a worldwide distribution in both developed and developing countries. Despite the amount of awareness created, soil and water transmitted parasitic disease still poses a threat, especially in undeveloped countries. In addition, the scarcity of reported data on soil and water transmitted parasites, the consumption of unsafe work area occurs in developed and developing countries. So, the prevalence and pathogenicity of soil and water transmitted parasites must be investigated throughout the world.

Acanthamoeba, Ascaris lumbricoides, Blastocystis and Strongoides stercoralis are known soil and water transmitted parasites ${ }^{16}$. Acanthamoeba species encompasses at least 15 species of free living amoebae that have been isolated from a wide range of environments ranging from natural habitats like soil, salt water and fresh water, to domestic sources like tap water, air conditioning units and sewage systems ${ }^{17}$. The researchers have been reported that Acanthamoeba (genotype 4) is pathogen and common in environmental sources ${ }^{18}$. We found that only Acanthamoeba (genotype 4) in soil and water samples as supported in previous studies about Acanthamoeba.

Acanthamoeba can attack the central nervous system leading to granulomatous encephalitis and target other organs such as the eyes, which end up with amoebic keratitis, as well as skin lesions in the patients with immunodeficiency, and in healthy individuals ${ }^{19}$. Some researchers 
have been reported that Acanthamoeba infections peaked in spring and early summer ${ }^{20}$. Although, we did not find any parasites in winter, we found Acanthamoeba (genotype 4) $22.3 \%$ of soil samples and $14.3 \%$ of water samples. This situation suggests that the prevalence of Acanthamoeba is high in summer.

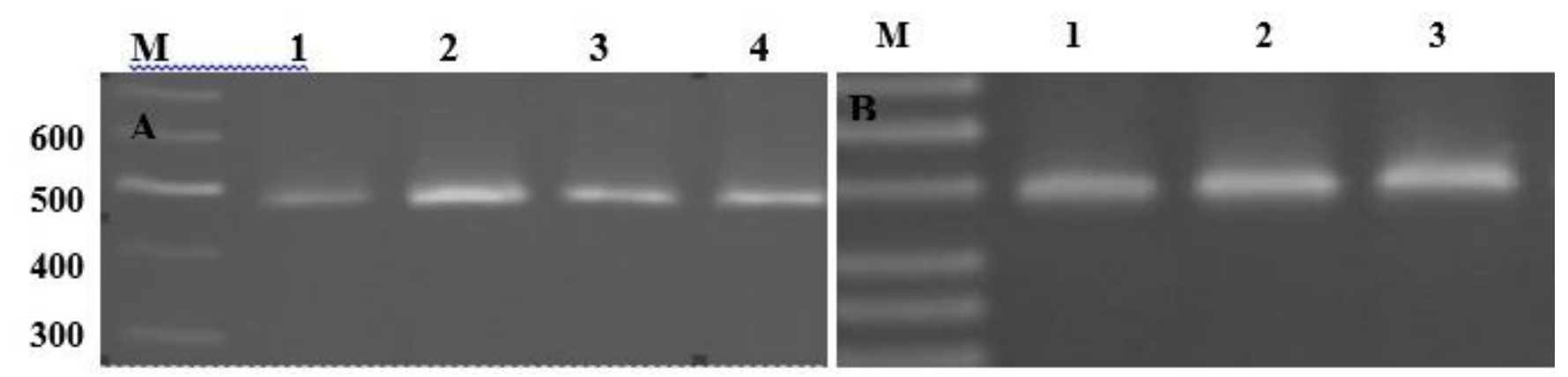

Figure 3: The results of PCR assay for identification of Acanthamoeba and Blastocystis genotyping in this study. M; 100bp-1000bp DNA Marker, Lanes 1-4; DNA of Acanthamoeba and Blastocystis. (A; Acanthamoeba B; Blastocystis)

Ascariasis is caused by Ascaris lumbricoides and ascariasis occurs with greatest frequency in tropical and subtropical regions and in any areas with inadequate sanitation ${ }^{21}$. The intestinal worms a large percentage of which is caused by ascariasis, and world-wide severe ascariasis cause approximately 60000 deaths per year, mainly in children it is largely a disease of people exposed to untreated wastewater or food grown on it ${ }^{21}$. We found $16.6 \%$ eggs of Ascaris lumbricoides in soil samples and this situation can occur ascariasis in public of Gaziantep province.

Blastocystis is one of the most common gut parasites found in the intestinal tract of humans and contaminated water was reported to be an important risk factor for Blastocystis transmission via the fecal-oral route ${ }^{22,23}$. Several researches have isolated Blastocystis from variety water such as river, drinking water $^{22}$. We isolated Blastocystis from water in Gaziantep Organized Industral Zone of southeast Turkey. The genus comprises at least 17 subtypes, nine of which (Subtype1Subtype9) have been isolated from human fecal samples ${ }^{24}$. There have been 13 subtypes reported with Blastocystis subtype3 shown to be the highest in Thailand with prevalence rates between 41.7-92.3\%; Egypt 54.55\%; Singapore 78\%; Turkey 75.9\%; Germany 21\% and France 53.5\% 25. Our results support previous studies, we found that $42.9 \%$ Blastocystis subtype 3 (which also known as pathogenic subtype) in water samples in this study.

Strongyloides stercoralis is a parasite, endemic in tropical, subtropical and also rarely in temperate regions, that infects up to 100 million people worldwide ${ }^{26}$. Infection usually results in asymptomatic chronic disease of the gut, which can remain undetected for decades. However, in patients receiving long-term corticosteroid therapy, hyperinfection can occur, resulting in high mortality rates (up to $87 \%)^{26}$. We searched for soil transmitted parasites prevalence rates and we found Strongyloides stercoralis (11.1\%) in soil samples. Our results showed that Strongyloides stercoralis live in soil and this parasite is a risk for people's health.

The potential for environmental contamination depends upon a variety of factors, including the number of infected non-human hosts, agricultural practices, host behavior and activity, socio-economic and ethnic differences 
in human behaviors, geographic distribution, sanitation, safety of drinking water and food sources $^{27}$. Furthermore the temperature is a major environmental factor and can affect the physiology, biochemistry and behavior of host and parasites ${ }^{28}$.

There are a lot of studies about prevalence of parasitic infections in different region of Turkey. They have reported that Ascaris lumbricoides, Blastocystis, Strongyloides stercoralis are frequently seen among intestinal parasites in or country. These studies showed that these parasitic infections are major public health problem in Turkey ${ }^{29-32}$. The prevalence of parasitic infections vary according to country's geographic location, sociocultural structure and climate change. In this study has been showed that the presence of soil and water transmitted parasites in Gaziantep Organized Industrial Zone in summer. This situation affects not only the people who live in Gaziantep but also people who migrate to find work in this province. We found that the risk of soil and water transmitted parasites in Gaziantep Organized Industrial Zone which there are a lot of migrant workers. These parasites can spread throughout the country when migrant workers return home, and the prevalence of these parasites can increase. Therefore, it is important to develop programs to promote awareness towards the existence of potential parasitic infections and future studies should be carried out to further explore these issues.

Acknowledgement: We would like to thank to Professor Dr. Mustafa Yllmaz who is member of Biotechnology Department and Medicine Faculty Pediatric Allergy and Immunology Department of Cukurova University for his support to our study.

Declaration of Conflicting Interests: The authors declare that they have no conflict of interest.

Financial Disclosure: No financial support was received.

\section{REFERENCES}

1.http://www.who.int/mediacentre/factsheets/fs366/e n (accessed 05 February 2017).

2. Magliano AC, da Silva FM, Teixeira MM, Alfieri SC. Genotyping, physiological features and proteolytic activities of a potentially pathogenic Acanthamoeba sp isolated tap water in Brazil. Exp Parasitol 2009; 123: 231-5.

3. Baldursson S, Karanis P. Waterborne transmission of protozoan parasites: review of worldwide outbreaksan update 2004-2010. Water Res 2011; 45:6603-14.

4. Pilotte N, Papaiakovou M, Grant JR, et al. Improved PCR-based detection of soil transmitted helminth infections using a next-generation sequencing approach to assay design. Plos Negl Trop Dis 2016; 10: e0004578.

5. Lorenzo-Morales J, Martin-Navarro CM, LopezArencibia A, et al. Acanthamoeba keratitis: an emerging disease gathering importance worldwide? Trens Parasitol 2013; 29:181-7.

6. Karanis P, Kourenti C, Smith H. Waterborne transmission of protozoan parasites: a worldwide review of outbreaks and lessons learnt. J Water Health 2007; 5:1-38.

7. Caroline Okeke 0, Obiageli Ubachukwu P. A crosssectional study of Ascaris lumbricoides infection in a rural community in Ebonyi State, Nigeria: prevalence and risk factors. Iran J Public Health 2015; 44:1430-2.

8. Pipatsatitpong D, Rangsin R, Leelayoova $S$, et al. Incidence and risk factors of Blastocystis infection in an orphanage in Bangkok, Thailand. Parasit Vectors 2012; 14:5:37.

9. Azizian M, Basati G, Abangah G, et al. Contribution of Blastocystis hominis subtypes and associated inflammatory factors in development of irritable bowel syndrome. Parasitol Res 2016; doi: 10.1007/s00436016-4942-4.

10. Ostera G, Blum J. Strongyloidiasis: risk and healthcare access for Latin American immigrants living in the United States. Curr Trop Med Rep 2016;3:1-3.

11. http://businessturkeytoday.com/gaziantep-ahistorical-town-and-a-major-industry-center-insoutheastern-turkey.html (accessed 29 March 2016).

12. Schroeder JM, Booton GC, Hay J, et al. Use of subgenic $18 \mathrm{~S}$ ribosomal DNA PCR and sequencing for genus and genotype identification of acanthamoebae from humans with keratitis and from sewage sludge. J Clin Microbiol 2001; 39:1903-11.

13. Yoshikawa H, Wu Z, Kimata I, et al. Polymerase chain reaction based genotype classification among human 
Blastocystis hominis populations isolated from different countries. Parasitol Res 2004; 92:22-9.

14. Ryan S, Hislop J, Ziebland S. Do we all agree what "good health care"looks like? Views from those who are "seldom heard" in health research, policy and service improvement. Health Expect 2017; doi: 10.1111/ hex.12528.

15. Koruk I, Simsek Z, Tekin Koruk S, et al. Intestinal parasites, nutritional status and physchomotor development delay in migratory farm worker's children. Child Care Health Dev 2010; 36:888-94.

16. Strunz EC, Addiss DG, Stocks ME, et al. Water, sanitation, hygiene, and soil-transmitted helminth infection: a systematic review and meta-analysis. Plos Med 2014; 11:e1001620.

17. Iovieno A, Ledee DR, Miller D, et al. Detection of bacterial endosymbionts in clinical Acanthamoeba isolates. Ophthalmology 2010; 117:445-52.

18. Evyapan G, Koltas IS, Eroglu F. Genotyping of Acanthamoeba T15: the environmental strain in Turkey. Trans R Soc Trop Med Hyg 2015; 109:221-4.

19. Bagheri H, Shafiei R, Shafiei F, Sajjadi S. Isolation of Acanthamoeba spp from drinking waters in several hospitals of Iran. Iran J Parasitol 2010; 5:19-25.

20. Magnet A, Fenoy S, Galvan AL, et al. A year long study of the presence of free living amoeba in Spain. Water Res 2013;47:6966-72.

21. Ashbolt NJ. Microbiol contamination of drinking water and disease outcomes in developing regions. Toxicology 2004; 198: 229-38.

22. Ithoi I, Jali A, Mak JW, et al. Occurrence of Blastocystis in water of two rivers from recreational areas in Malaysia. J Parasitol Res 2011;123916.
23. Ragavan ND, Kumar S, Chye TT, et al. Blastocystis sp in irritable bowel syndrome (IBS) detection in stool aspirates during colonoscopy. Plos One 2015; 10: e0121173.

24. Poruk S, Udomsom R, Koompapong K, et al. Subtype distribution of Blastocystis in Thai-Myanmar border, Thailand. Korean J Parasitol 2015; 53:13-9.

25. Ragavan ND, Govind SK, Chye TT, Mahadeva S. Phenotypic variation in Blastocystis sp ST3. Parasit Vectors 2014; 29: 7:404.

26. Siddiqui AA, Berk SL. Diagnosis of Strongyloides stercoralis infection. Clin Infect Dis 2001; 33: 1040-7.

27. Slifko TR, Smith HV, Rose JB. Emerging parasite zoonoses associated with water and food. Int J Parasitol 2000; 30: 1379-1393.

28. Shim KC, Koprivnikar J, Forbes MR. Variable effects of increased temperature on a trematode parasite and its intertidal hosts. J Exp Mar Bio and Eco 2013; 61-8.

29. Cicek M, Yılmaz H. Prevalence of Cryptosporidium spp and other intestinal parasites in children with diarrhea. Dicle Med J 2011; 38:70-5.

30. Tascengiz Z, Beyhan YE, Cicek M, Yllmaz H. Intestinal and hepatic parasites determined in a university hospital parasitology laboratory. Dicle Med J 2015; 42: 350-4.

31. Karaman U, Kolören Z, Demirel E, et al. The presence of parasites in the waters of Giresun province. Dicle Med J 2016; 521-6.

32. Firat Z, Gecit I, Depecik F, et al. Frequency of intestinal parasites in employees of a state hospital. Dicle Med J 2010; 37: 267-71. 